НАУКОВИЙ ВІСНИК

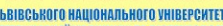
РИнаРНӦ̈ МЕДИИИНИ ТА БОТЕКНОЛО імені С.3. гжищьког Scientific messenger of Livi National Unirersity
Veterinary Medicine and Biotechnologies

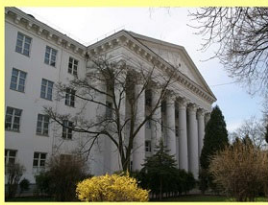

СЕРІя "ЕКономІчн НАУК

Том 21 № 93 2019
Науковий вісник Дьвівського національного університету ветеринарної медицини та біотехнологій імені С.3. Гжицького. Серія: Економічні науки

\author{
Scientific Messenger of Lviv National University \\ of Veterinary Medicine and Biotechnologies. \\ Series: Economical Sciences
}

ISSN 2519-2701 print

https://nvlvet.com.ua/index.php/economy

doi: 10.32718/nvlvet-e9317

\title{
Problems of science and ethno national relations in Ivan Franko's socio-political heritage
}

\author{
P.G. Berko, M.M. Dzera
}

Stepan Gzhytskyi national university of veterinary medicine and biotechnologies Lviv, Ukraine

Article info

Received 16.09.2019

Received in revised form 17.10 .2019

Accepted 18.10.2019

Stepan Gzhytskyi National University of Veterinary Medicine and Biotechnologies Lviv, Pekarska Str., 50, Lviv, 79010, Ukraine.

Tel.: +38-067-309-14-96 E-mail: philosophy@lvet.edu.ua
Berko, P.G., \& Dzera, M.M. (2019). Problems of science and ethno national relations in Ivan Franko's socio-political heritage. Scientific Messenger of Lviv National University of Veterinary Medicine and Biotechnologies. Series: Economical Sciences, 21(92), 86-91. doi: 10.32718/nvlvete9317

The article points out that the starting of the analysis of Ivan Franko's views on the problem of ethno national relations is to determine the place and sole of national foundations in the development of humanity, through which society must absorb the most progressive assets. He emphasize: and here the synthesis of all of the ideal competitions, the structure to which all the bricks must go, will be the ideal of complete, unbound and unbounded (except voluntary concessions, which reguine of friendly life with neighbors) life and development of the nations. Anything that goes outside the nations in his, or the Pharisee of people who, by international ideals, would like to cover their competition for domination of the nation over another, or the painful sentimentalism of science - fictions writers who would like to cover their spiritual alienation from their native nation with road, human phrases. As we can see, it is the nation itself, no the class struggle, that is the crystallizing beginning, the strongest factor that unites people into the community and the state. Thus, the reflections of Ivan Franko also confirm that he was completely free from the political influence of materialism and the transition to the foundations of idealism. Defending the natural right of the nation to political independence, the writer strongly opposes any national oppression, associating it with the negative consequences and degradation of "not only the weak but also the strong". "About no oppression, no apostasy, whether religious or national, or any other of our ideals or languages. No religion, no conviction, no trait and no nationality were and cannot be the subject of our hatred". Such an object was and still is only oppression, every exhortation and every fallacy. Determining the essence of the nation, its place and role in the progress of human civilization naturally brought Ivan Franko to thinking about ways to solve the national question, the principles of national-state construction. He advocated the full, unrestricted freedom of life and development of the nation, being deeply convinced that there are no people of "inferior and supreme: all are equal and have equal right and free development". In addition, Ivan Franko warns that their own establishment is possible in close connection with other people. The thinker is confident of success on the path of national self affirmation of our people, but this path is not easy, every conscious Ukrainian should make every effort. In doing so, we must adhere to our moral principles. Free and successful development of a nation can be realized in certain unifying principles. One of these principles, according to Ivan Franko, is nationalism, patriotism and language. And one more, we think, the actual advise of the thinker, to help people get out of their current situation. You need to look for a path to progress.

Key words: Ivan Franko, patriotism, language.

\section{Проблеми нації $\mathrm{i}$ етнонаціональних відносин у суспільно-політичній спадщині Івана Франка}

\author{
П.Г. Берко, М.М. Дзера
}

Львівський національний університет ветеринарної медицини та біотехнологій імені С.3. Гюсицького, м. Львів, Україна

У статті зазначається, щзо відправною точкою аналізу поглядів I. Франка на проблему етнонаціональних відносин є визначення ним місия і ролі національних засад у розвитку у розвитку людства, через які суспільство має засвоювати найпрогресивніші 
надбання. Він наголошує: “А тут синтезом усіх ідеальних змагань, будовою, до якої повинні іти всі цеглини, буде ідеал повного, нічим не зв'язаного і не обмежуваного (крім добровільних концесій, яких вимагає дружне життя з сусідами) життя і розвитку начіï. Все, щчо йде поза дами нації, се його або фарисейство людей, щуо інтернаціональними ідеями раді би прикрити свої змагання до панування одної нації над другою, або хворобливий сентименталізм фантастів, щуо раді би широкими “вселюдськими фразами покрити своє духовне відчуження від рідної нації”. Як бачимо, щчо саме нація, а не класова боротьба є тим кристалізаційним началом, найсильнішим чинником, які єднають людей у спільноту і державу. Так роздуми I. Франка також засвідчують, цио він цілковито звільнився від політичного впливу матеріалізму і перехід до основ ідеалізму. Обстоюючи, закономірне право нації на політичну самостійність,письменник рішуче виступає проти всякого національного гніту, пов'язуючи його з негативними наслідками і деградацією “не тільки слабого, але й сильного”. “Про жодне гноблення, про жоден визиск, про жодну апостазію чи то релігійну, чи національну, чи яку іншу в наших ідеалах ані мови. Жодна релігія, жодне переконання, жодна раса і жодна народність не були й не можуть бути предметом нашої ненависті". Таким предметом були і залишається на все тільки усякий утиск, усякий визиск і всяка облуда. Визначення сутності нації, ї̈ місия і ролі в поступі людської цивілізації закономірно наближали I. Франка до роздумів про шляхи вирішення національного питання, принципи національно - державного будівництва, Він виступав за повну, нічим не обмежену свободу життя і розвою нації, будучи глибок переконаним у тому, щзо немає народів “нижчих $і$ вищих: усі $є$ рівними і мають рівне право вільний розвиток”. Крім цьього I. Франко застерігає, щуо власне становлення можливе у тісному зв'язку з іншими народами. Мислитель впевнений у досягненні успіху на шляху національного самоутвердження нашого народу, але цей шлях не легкий, кожний свідомий українець повинен прикласти максимум зусиль. При цььому у своїй діяльності ми повинні дотримуватись моральних засад. Вільний і успішний розвиток нації може бути реалізований у певних об'єднуючих началах. Одним з таких начал, на думку І.Франка, є націоналізм, патріотизм і мова. I ще одна, ми так вважаємо, актуальна порада мислителя, допомогти людям вийти з нинішнього складного становища. Необхідно шукати дорогу до поступу.

\section{Ключові слова: Іван Франко, патріотизм, мова.}

У реальному житті в час певних труднощів, невизначеності, сумнівів ми за порадою звертаємося до авторитетних особистостей. Саме нині виникла потреба порадитися з такою особистістю з проблем нації і етнонаціональних відносин в Україні. Такою особистістю є Іван Франко - найвизначніший український мислитель другої половини XIX - початку XX ст., невтомний борець за національну волю свого народу, символ українського відродження.

I. Франко у своїх багатьох працях простежує українське національно-культурне відродження. На його думку, це відродження має своє джерело в історичній традиції і в пробудженні української народності.

Перша традиція збереглася в Гетьманщині та в Слобідській Україні. Лівобережна Україна мала політичну і культурну автономію, і це сприяло тому, що саме тут відродилася культура, нова народна література. Тут у другій половині XVIII ст. з'явився мудрець і вчитель, музикант, поет, вільнодумець на імя Григорій Скоровода. Під його безпосереднім впливом у Харкові відкривають перший на східноукраїнських землях університет. У цей час Іван Котляревський написав перший поетичний твір українською мовою травестовану “Енеїду”. Під впливом західноєвропейських ідей повсюдно пробуджується нове життя, утверджується ідея народності. На історичній арені з'являються такі особистості, як П. ГулакАртемовський, Григорій Квітка, Микола Гоголь, Тарас Шевченко та багато інших. (Див. Конкретніше I. Франко “Українці” Збір. творів: У 50 т. - Київ: Наукова думка, 1986 - т. 41, с. 162-193. Далі посилаємось на це видання скорочено, зазначаючи арабськими цифрами том і сторінку).

Появляються праці з української історії, філософії, етнографії, літератури, і тоді поняття народності набирає іншого змісту. Нова національна література, за словами I. Франка, одне із головних завдань вбачала у психологічному аналізі соціальних явищ, у тому, сказати б, як факти громадського життя відбуваються в душі і свідомості одиниці, і навпаки, як у душі тої одиниці зароджується й виростають нові події соціальної категорії (т. 34, с. 363 ). В історії нашого роз- вою, продовжує письменник, нова, національна література була тим лісом, в котрім є й дуби, $є$ й ліщина, але все разом має одноцільний характер, - відразу видно, що се ліс, а не степ, що се витвір колективної праці духовної, незрілих загальних змагань усієї суспільності, а не одрізнені прояви поодиноких, самотніх, хоч би й великих талантів (Franko, 2004).

Відомо, що життя людини, іiі праця, громадська поведінка залежить від “тисячі сторонніх впливів, від успадкованих інстинктів свої раси, від виховання, суспільного становища, лектури, заняття, від впливу людей і природи" (т. 28, с. 182). Більш грунтовнішу оцінку історичного процесу того часу I. Франко дає у праці "Нарис історії українсько-руської літератури до 1890 р.” (т. 41, с. 194-470). Разом з тим варто зазначити, що праця письменника була не лише аналізом минулого, а й стала міцним фундаментом для наступних пошуків українських вчених (С. Смаль-Стоцький, Я. Ярема, І. Мірчук та ін.) Фундаментальним для Івана Яковича було положення про самооцінність, одність нації. Він вважав помилковим судити про свій народ за критеріями оцінки інших, без акцентування на власній природі, тобто базуватися на сковородівській формулі: пізнай самого себе. Ця засаднича теза має у його обгрунтуванні історичний соціокультурний та психологічний аспекти і була скерована на вироблення політичної орієнтації у конкретній ситуаціï.

Крім цього, I. Франко застерігає, власне становлення можливе у тісному зв'язку з іншими народами: “Мусимо зрозуміти, що кожен крок внутрішньої культурної праці, кожна діяльна школа, кожна тисячами прочитана брошура, кожен твір штуки, що вірно малює нашу національну вдачу, кожний наш вклад у скарбницю вселюдської науки дорожчий для нас від хвилевих ораторських успіхів, від хвильового призначення або похвали чужинців... Інтереси нашої нації нерозривно зв'язані з інтересами свободи, поступу та людяності" (т. 47, с. 322-323). При цьому не повинні забувати, що “економічні й соціальні відносини цілого народу переробити чи перевернути - діло нелегке i переходить сили не то кількох одиниць чи груп, але 
цілих поколінь. Але, з другого боку, ми переконалися, що “дух бодр, плоть же не могила”, що праця одного покоління, а навіть невеликої, але рішучої та інтелігентної групи серед того покоління може мати великий вплив на зміну духовного стану, настрою й упособлення цілого народу” (т. 41, с. 527). Мислитель впевнений у досягненні успіху на шляху національного самоутвердження нашого народу. Але цей шлях нелегкий, кожний свідомий українець повинен прикласти максимум зусиль, бо: “Наша побіда над противними нам силами буде не одним великим і рішучим ударом, не якимсь катаклізмом, а сумою безчисленних, дрібних, буденних побід, незначних, тихих, а зріло обдуманих і неумолимою працею здобутих. Менше крові, а більше поту! - се повинен бути оклик нашої будущої історії” (т. 46. Кн. 1. с. 321). Крім цього, при усій затраченій енергії, нас не повинно покидати почуття бажання жити i віра у промислове майбутнє. Таку перспективу становлення I. Франко подає у статті: "Тарас Шевченко": “Свобідне життя, всесторонній, нічим не опутаний розвій одиниці і цілої суспільності, цілого народу, - се ідеал Шевченка, котрому він був вірний ціле життя. Неволя і переслідування - чи то народне, політичне, суспільне чи релігійне - мали в нім непримиримого ворога. Бажання життя пробивається в усіх його творах як золота нитка 3-посеред різнобарвної тканини. Індивідуальність - людська без огляду на стан, народність і віру - $є$ для нього свята" (Franko, 2004). В оцінці творчості Т. Шевченка I. Франко підтримує думку Кобзаря, що у своєму поступі ми повинні пам'ятати права особи, і1і унікальність і створити можливості для вільного вибору власної долі.

Крім того, наголошує І. Франко у праці “Поза межами можливого”, що у будь-якій сфері людської діяльності, чи людина працює фізично чи інтелектуально, чи зносить тяжкі труди для власного добра, чи для добра родини або цілої нації, чи бореться вона зі зброєю в руках за краще майбутнє своєї Батьківщини, завжди і всюди іiі діяльність підлягає моральному осуді. Мораль - один з основних способів нормативної регуляції дій людини в суспільстві, особлива форма суспільної свідомості і вид суспільних відносин, що охоплює погляди і почуття, життєві орієнтації та принципи, цілі та мотиви вчинків, проводячи межу між добром і злом, чесно і безчестя, справедливості і несправедливості, нормою і ненормованістю, милосердям і жорстокістю тощо. Моральна оцінка стає необхідним компонентом всяких проявів життя, якщо ми хочемо залишатися в межах культури. Немаловажну роль відіграє і вольовий чинник, важливо також позбутися матеріалістичного і позитивніських поглядів на історію: "Виплоджений так званим матеріалістичним світоглядом фаталізм, який твердив, що певні (соціальні, разом з тим, політичні) ідеали мусять бути осягнені самою “іманентною” силою розвою продуктивних відносин, без огляду на те, чи ми схочемо задля свого кивнути пальцем, чи ні, належить сьогодні до категорії таких самих забобонів, як віра в відьм, в нечисте місце і феральні дні. Ми мусимо серцем почути свій ідеал, мусимо розумом уяснювати собі його, мусимо вживати усіх сил і засобів, щоб набли- жуватися до нього, інакше він не буде існувати і ніякий містичний фаталізм не створить його там, а розвій матеріальних відносин перший потопче і роздавить нас, як сліпа машина (там само... с. 417). Побороти усі негаразди і вистояти може націоналізм ідеологія та напрям політики, з базовим принципом про цінність нації як вищої форми суспільної єдності та іiі первинності в державному процесі. "Все, зазначає I. Франко, - що піде поза рамки нації, се або фарисейство людей, що інтернаціональними ідеалами раді би прикріпити свої змагання до панування одної нації над другою, або хоробливий сентименталізм фантастів, що раді би широкими “вселюдськими" фразами покрити своє духовне відчуження від рідної нації (там само... с. 416).

Хочемо звернути увагу на статтю I. Франка "Інтернаціоналізм і націоналізм у сучасних літературах". Ми погоджуємось 3 дослідниками творчості письменника, що він у цій праці дає дещо однобічну і упереджену оцінку суспільному явищу - об'єднанню Німеччини в імперію. Зміщення Німецької держави у 1860-80-их рр. супроводжувалося наростанням німецького націоналізму (який І. Франко називає шовінізмом проповіддю національної виключеності). Разом 3 тим, у нас виникають сумніви, чи до кінця ми зрозуміли роздуми I. Франка про шовінізм. 3 часом шовінізм у Німеччині переріс у нацизм, політичний рух, ідеологію, державний режим. Нацизм як світоглядний напрям та ідеологія був поєднанням еміратних та расистських (переважно антисемітських) концепцій, що намагалися обгрунтувати права Німеччини на завоювання інших народів і панування над світом. (Universalnyi slovnyk - entsyklopediia, 2001). I. Франко чітко сформулював “ідеал національної самостійності”, який не тільки вміщує в собі “західноєвропейські ідеали соціальної рівності і політичної волі”, але “один тільки може дати їм поле до повного розвою”. Мислитель як остережливе повчання 3 історичного досвіду для прийдешніх поколінь з болем у серці нагадував, що “не маючи в душі сього національного ідеалу, найкращі українські сили тонули в общеросійськім морі, а ті, що лишилися на своєму грунті, попали в зневіру і апатію" (Вибрані твори у трьох томах Т. 3 с. 415). Враховуючи та глибоко осмисливши історичний досвід, I. Франко предметно оцінив роль і значення “національної самостійності”, що $є$ єдиною гарантією економічного, соціального й політичного розвитку українського народу, прогресу його матеріальної та духовної культури. А тому, зазначає він, “синтезом усіх ідеальних змагань, будовою, до якої повинні йти всі цеглини, буде ідеал повного, нічим не в'язаного і не обмежуваного (крім добровільних концепція яких вимагає дружнього життя 3 сусідами) життя і розвою нації. "Ідеал національної самостійності”- це провідна зірка на важких та крутих дорогах національно-визвольної боротьби українців, основоположна ідея його національної свідомості. Формування національної свідомості - це усвідомлення над цією, утворюючими іiі групами та спільнотами процесів самостійницького життя через призму відповідних інтересів і цінних орієнтацій. Така свідомість може бути більшою або меншою мірою адекватним відо- 
браженням об'єктивних процесів боротьби за державу та реалізацію потреб самостійного розвитку нації. I. Франко дуже добре розумів, що на початку XX ст. “ідеал національної самостійності в усякім погляді культурнім і політичнім, лежить для нас поки що, з нашої теперішньої перспективи поза межами можливого" (там само, с. 417), але він прекрасно усвідомлював ще й те, що без розуміння та сприйняття цього ідеалу український народ чекає остаточна загибель. Життєве завдання й полягає в тому, що “тисячні стежки, які ведуть до його осущення, лежать просто таки під нашими ногами, і що тільки від нашої свідомості того ідеалу, від нашої згоди на нього буде залежати чи підем тими стежками в напрямі до нього, чи, може, звернемо на зовсім інші стежки" (там само с. 417). Для мислителя характерний цілісний підхід до проблеми національної самостійності. І. Франко у зверненні до галицької молоді робить спробу проаналізувати суспільну специфіку того часу: “Перед українською інтелігенцією відкривається тепер, при свобідніших формах життя в Росії, величезна дійова задача витворити 3 величезної етнічної маси українського народу українську націю, суспільний культурний організм, здібний до самостійного культурного й політичного життя, відпорний на асиміляційну роботу інших націй, відки б вона не йшла та при тім податний на присвоювання собі в якнайширшій мірі в якнайшвидкім темпі загальнолюдських культурних здобутків, без яких жодна нація і жодна хоч і як сильна держава не може остоятися" (там само, с. 570). Але для цього ми повинні усвідомити своє українське “Я”, якнайшвидше, якнайосновніше змінити курс нашого національного корабля, настроїти всі наші думки, плани, програми на інший діапазон. 3 цього приводу він продовжує: "Ми мусимо навчитися чути себе українцями - не галицьким, не буковинськими українцями, а українцями без офіційних кордонів. I це почуття не повинно бути голою фразою, а мусить вести за собою консеквенції” (лат. - послідовний П.Б.) (там само, с. 571).

У XVIII-XX ст. поряд 3 вимогою утворення самостійної держави ("Вивід прав України” П. Орлика, "Ukraina irredenta" Ю. Бачиневського, "Самостійна Україна" М. Міхновського та ін.) поширились саме федеральські ідеї про перебудову Російської імперії на демократичну федерацію 3 рівним національним суверенітетом (автономією) народів, які іiі населяли, Україна мала зайняти місце в цій федерації нарівні 3 іншими.

Федералістсько-демократична традиція української думки знайшла втілення у творчості I. Франка. Він, зокрема, визначав такі ступені реалізації принципу федералізму:

1) створення федерації в межах возз'єднаної України;

2)

3) об'єднання слов'янських націй в єдину федерацію;

4) оформлення всесвітньої федерації. Вбачаючи вирішення національного питання (українського, польського та ін) в федеральному зв'язку між собою та іншими сусідами, у зв'язку побудованому на самому повному рівноправ'ї і автономії кожного окремого народу, він уявляв майбутнє об'єднання людей світу у вигляді всесвітньої федерації демократичних республік. Разом з тим I. Франко застерігав, що федералістичний устрій сам собою не мусить вести до добра, а навпаки, може вести до великого лиха... Головною основою такого устрою повинна бути шляхетна рівність (див. конкретніше т. 45, с. 19).

На першому місці, - продовжує він - повинні бути інтереси поодинокої нації як найбільшої одиниці, яку чоловік може обняти своєю практичною працею (т. 45 , с. 25 ).

Вільний і успішний розвиток нації може бути реалізований у певних об'єднуючих началах. Одним 3 таких начал, на думку I. Франка, є націоналізм. патріотизм і особливо мова. I хоча ми не знайшли класичного визначення поняття націоналізму у нашого мислителя, зазначимо: його роздуми про життєздатність націоналізму нині актуальні як ніколи. Націоналізм I. Франка полягав за повернення зросійщеної людності до рідної національної культури; наданні українському рухові цивілізованого спрямування, щоб він не був знесений стихійним потоком; був спрямований на розвиток національної гідності, самоповаги, національної віри. Небезпекою, - зазначає I. Франко, - $є$ те, що деякі націоналісти, прикриваючись високими словами, опускають саме головне, проблеми свого народу. "Нація, котра помирає з голоду, в котрій 90\% людей не вміє ні читати, ні писати і не має де facto (лат. фактично) ніякої політичної волі - така нація потребує хліба, азбуки і конституції; театрами, концертами “національними”, романами і поезіями дуже мало їй можна прислужитися” (т. 27, с. 356). “Але се була тільки мала часть горя, - пише I. Франко. Далеко гірше було те, що в значній частині української суспільності запанував був настрій байдужий, а навіть ворожий для розвою української національності" (т. 41, с. 472). Мислитель 3 гірким почуттям і засудженням дає оцінку таким націоналістам за їхню недалекоглядність і обмеженість, безперспективність боротьби. "Ви бачите, - зазначає письменник, - лише два виходи: або погибати по мимо всяких голосінь о повній самотності, або ждати якого-небудь чуда, якоїь європейської катастрофи котра б одірвала Україну од Росії (т. 27 с. 357). Залишається надіятись, що справжні і поважні люди візьмуть верх над тими, за словами старого Софоула, “мабуть, вітряками вродились - та й мелють” (див. там само, с. 357). Щоб оцінити цінність нації, необхідно бути зі своїм народом, жити його житиям, бути "неначе дерево, що своїм корінням впивається якомога глибше і міцніше в свій рідний національний грунт, намагається ввіссати в себе і переварити в собі якнайбільше його живих соків, а своїм пнем і короною поринає в інтернаціональній атмосфері ідейних інтересів, наукових, суспільних естетичних і моральних змагань. Тільки той писатель може нині мати якесь значення, хто має і вміє цілій освіченій людськості сказати якесь своє слово в тих великих питаннях, що ворушать іï душею, та заразом сказати те слово в такій формі, яка б найбільш відповідала національній вдачі. I тільки такий 
писатель буде рівночасно зрозумілий і цікавий не тільки для своїх найближчих земляків, але й для цілого цивілізованого світу, бо всі знайдуть у його творах, хоч i яка була би незвичайна та оригінальнонаціональна їх форма". (т. 31, с. 34).

Націоналізм у I. Франка переплітається з патріотизмом. Для нього патріотизм - одне 3 найглибших почуттів, яке закріпилося усе його свідоме життя: почуття любові й прив'язаності до рідних місць, України. Патріотизм у нього - це діяльне ставлення, національна гордість і любов до Батьківщини, громадянська відповідальність за іiі долю. Патріотизм, на думку I. Франка, має бути не пасивно-світоглядним, споглядальним, мітингом. Навпаки, він має бути активним, не тільки в добу великих історичних потрясінь, в період національно-визвольних змагань, а й у повсякчасній праці на благо Батьківщини. У вірші: “Сідоглавому” і статті “Дещо про себе самого” письменник розкрив принципову різницю між своїми почуттями патріотизму і лицемірним “патріотизмом" “народовців”. “Як син селянина-русина, вигодований чорним селянським хлібом, працею твердих селянських рук, почуваю обов'язок панщиною всього життя відробити ті теляги, які видала селянська рука на те, щоб я міг видряпатися на високу, де видно світло, де пахне воля, де ясніють вселюдські ідеали. Мій руський патріотизм - то не сентимент, не національна гордість, то тяжке ярмо, покладено долею на мої плечі. Я можу здригається, можу тихо проклинати долю, що поклала мені на плечі це ярмо, але скинути його не можу, іншої Батьківщини шукати не можу, бо став би підлим перед власним сумлінням. I якщо щось полегшує мені нести це ярмо, так це те, що бачу руський народ, який хоч гноблений, затемнюваний і деморалізований довгі віки, який хоч і сьогодні бідний, недолугий й безпорадний, а все-таки поволі підноситься, відчуває в щораз мирних масах жадобу світла, поради та справедливості і до них шукає шляхів. Отже, варто працювати для цього народу і ніяка праця не піде на марне (т. 31, с. 31). Вважаємо, що коментарі тут зайві. Одне лише зазначимо: як нам нині не вистачає таких людей і з таким сумлінням.

I. Франко чітко усвідомлював, що у становленні нації новітнього типу вирішальну роль покликана відігравати інтелігенція, вносячи в маси національну ідеологію. Використати наукове поняття інтелігенції (від лат. - обізнаний, розсудливий знавець, фахівець) - мисляче творче ядро освіченої верстви, яке характеризується великою розумовою, естетичною та моральною активностю, ініціативою і творчістю, І. Франко не міг. Специфіка була така, що частина майбутньої інтелігенції ще не відбувалася, а інша частина вже сформованої інтелігенції обрала хиткий шлях. Про першу частину мислення пише: "Не заімпонуємо ми українцями і своєю інтелігенцією, своїм рівнем теоретичної освіти. Лиха доля змусила нас виростати i вчитися в краю, де завдяки шляхетському режимові наука вважається небезпечним оружжям, якого не слід давати в руки суспільності, де шкільне навчання в самім зароді затруєне конфесійними, політичними та національними пересудами, де свобідна критика виелімінувала 3 виховання, де панує так зване
Brotstudium, навчання для хліба, для кар'єри, навчання, тісне та далеке від тої широкої гуманності, що лежить в основі західноєвропейського вищого шкільництва" (Franko, 2004).

I. Франко добре орієнтувався і розумів цю версію населення. "Ми, - продовжує він, - не думаємо винуватити за те наших так званих інтелігентних людей. Вони не самі своєю волею зробились такими. Вони витвір виховання, школи, навколишніх обставин, i силою приноровлення до тих обставин мусили втиснути ся в ту мертвлячу форму, котру найшли вже готовою. Ми самі вийшли 3 тої самої школи, і добре знаємо скільки важкої довголітньої внутрішньої боротьби стоїло нам - вириватися з тої форми і переродитися духом до праці для народу" (т. 45, с. 150).

I. Франко з глибоким смутком писав про талановитих, але нещасливих людей, котрі сковані ланцюгами соціальної неволі, не змогли прикласти “до діла те знання, яке вони в житті здобули, ані ту щиру любов, котрою душа їх горіла в найкращих хвилях життя” (т. 27, с. 7). Разом з тим у такій критичній ситуації піднімалися загартовані особистості. Бо ж зло, кривда народові - це приниження гідності і кожної індивідуальності, яка почуває себе часткою того народу. На його думку, такою особистістю був Володимир Самійленко: "Він не декадент і не символіст, не модерніст і не консерватист, не революціонер і не реакціонер. Він поперед усього чоловік з ніжним людським почуттям, з вродженою і життям виробленою симпатією до всього бідного, покривдженого і зневаженого в природі і суспільності. При тім він українець, свідомий українець, усе душею відданий своїй країні i своєму народові... От тим-то він такий дорогий і любий кожному українському серцю, такий саморідний та національний - не штучний, а немов так готовий уже виріс з рідного грунту. Він живо відчуває всі зневаги і всі - на жаль, такі нечисленні - радощі рідного народу. Нема такої народної болячки, яка б не збудила відгуку в його серці, яка б у тім чудотворнім серці не скристалізувалася в ясну, чисту перлину правдивої поезї” (т. 37, с. 201).

I. Франко не втрачає оптимізму щодо ролі української інтелігенції “я бажаю тільки одного - звернути увагу всієї суспільності на ту історичну хвилю, якої наближення чуємо всі (письменник заздалегідь відчув події в Росії у 1917 р. П.Б.). Нам прийдеться змобілізувати всі свої сили, щоб задоволити потреби тої хвилі. Та поки ще вона не надійшла, до праці, молоді приятелі, до інтенсивної, невсипущої праці над собою самими! Здобувайте знання, теоретичне і практичне, гартуйте свою волю, виробляйте себе на серйозних, свідомих і статечних мужів, повних любові до свого народу і здібних виявляти ту любов не потоками шумних фраз, а невтомною, тихою працею. Таких мужів потребує кожна нація і кожна історична доба, коли всій нашій Україні перший раз у ії історичному житті всміхнеться хоч трохи повна горожанська і політична свобода" (Franko, 2004).

I. Франко акцентує нашу увагу на те, що складовою частиною розвитку організму нації $є$ матеріалізоване слово - мова. Людина, яка втратила мову - неповноцінна, вона другорядна в порівнянні 3 носієм 
рідної мови. Мова росте елементарно, разом з душею народу. Звідси - чим вищий рівень національного мовлення як першоознаки інтелектуально-духовної атмосфери, тим вищий рівень свідомості людей, а значить - i їх прагнення до державності своєї нації як гаранта соціальної справедливості. На думку Олександра Потебні, “мова - містичне ядро нації, тобто щось об’єктивно дане, що живе у підсвідомих глибинах етнографічної маси, та що може видобутися на поверхню свідомості і стати кермачем усіх національних змагань у всіх ділянках життя" (Chekhovych, 1931). "Ми не могли дати міліонам у руки хліба, - зазначає I. Франко, - не могли тисяч і соток тисяч охоронити від нужди, від еміграції, від визиску, від змарнування сил. У нас був тільки один знаряд - живе рідне слово. I можемо сказати собі, що ми не змарнували його, не закопали в землю, але чесно і совісно вжили на велике діло. I коли сьогодні те наше рідне слово блискотить багатством, красою й силою і знаходить відгомін у серцях соток тисяч синів України-Русі, розсипаних капризами долі по обох півкулях землі, коли воно здобуває собі, а разом із тим цілій нашій нації право горожанства серед цивілізованих народів, коли розтіч серед нашої суспільності зменшилась в прямій пропорції зі зменшенням числа анальфабетів, то все те гарний доказ на те, що слово, те марне летюче слово, найбільше бачилось би, хвилевий і нетривкий витвір людського духу, проявило чудотворну силу, починає двигати з у випадку ту масу, якій, бачилося, не було порятунку" (т. 41, с. 527-528). У даному контексті варто звернути увагу на грунтовий погляд I. Франка на рідну мову, у цьому явищі бачить велику невичерпну тайну людського існування - морального, психологічного та духовного, що пов'язується з сутністю буття народу: “Здається, що таке рідна мова? Чим вона ліпша для мене від усякої іншої, і що мені вадить при нагоді замінити іiі на усяку іншу? Практик, утилітарист скаже: пусте питання! Мова спосіб комунікації людей з людьми, маючи до вибору, я беру ту , яка дає мені можливість комуну куватися з більшим числом людей. А тим часом якась таємна сила в людській природі каже: pardon, ти не маєш до вибору; в якій мові родився і виховався, тої без окалічення своєї душі не можеш покинути, так як не можеш замінятися 3 ким іншим своєю шкірою. І чим вища, тонша, субтельніша організація чоловіка, тим тяжче дається i страшніше карається йому така переміна" (Franko, 1905). Тому мислитель гостро критикує зрусифікованих та спольщених українських інтелігентів, які зреклися свого народу, мови і які служать чужим для українського народу силам. I. Франко у праці “3 кінцем року” зазначає: “Сором українській інтелігенції, сором особливо молодому поколінню, коли воно не відчуває тої великої потреби, не віднайде шляху до народу", не покладе основи для того, щоб Україну зробити політичною силою" (Franko, 1896). I хоча ці слова були написані 120 років тому, нині вони актуальні як ніколи. I ще одна, на нашу думку, актуальна порада I. Франка, що необхідно зробити, щоб допомогти людям вийти 3 нинішнього складного становища: “на се одна відповідь: шукати дороги до поступу, але не такого як досі, їх не задовольняє сам поступ багатства; вони питають: а в чиїх руках се багатство, хто й на що користується ним? Її не задовольняє сам поступ науки й штуки; вони хочуть, аби наука і штука була власністю усіх людей, прояснювала їх розум і звеселяли життя. Як бачимо, обік зросту багатства, науки i штуки зросло також почуття милосердя, любові до людей, справедливості. Люди починають переконуватися, що само багатство, сама наука, сама штука не може дати чоловікові повного щастя. Наскільки чоловік може бути щасливим у житті, він може се тільки в співжитті з іншими людьми, в родині, громаді, нації. Скріплення, уточнення того почуття любові до інших людей, до родини, до громади, до свого народу от се основна підвалина всякого поступу, без неї все інше буде мертве тіло без живої душі в ньому" (Franko, 2004).

Сучасні тенденції глобалізації, мультикультуралізму, шовіністичного реваншу зі сторони окремих країн особливо роблять проблему мовного розвитку у площині національних вартостей. Перспективи національного розвою тісно пов'язані з процесами самоусвідомлення кожного громадянина зокрема i народу загалом. А таке самоусвідомлення неможливе без усвідомлення відповідальності за власну мову та іiі майбутнє.

Таким чином, Іван Франко на основі синтезу величезного історичного, філософського, літературного, етнографічного та іншого матеріалу робить висновок, що український народ здатний збудувати самостійну і могутню національну державу. Ми підтримуємо думку великого знавця української проблематики Клеренса Манінга, що Іван Франко був завжди і залишається “скульптором модерної нації” (Основи творчого методу Івана Франка Вибране - т 1 - Мюнхен 1971 с. 31). А нам залишається надзвичайно копітка праця над всеохоплюючою спадщиною Івана Франка.

\section{References}

Chekhovych, K. (1931). Dumky O. Potebni pro natsionalnist. Lviv (in Ukrainian).

Franko, I. (1896). Z kintsem roku. Zhyttie i slovo. t. 6. Kn. 6. Lviv (in Ukrainian).

Franko, I. (1905). Dvoiazychnist i dvolychnist. LNV. t 30 Kn IV Lviv (in Ukrainian).

Franko, I. (1986). Zbirnyk tvoriv: u 50 tomakh, Kyiv, 1976-1986 (in Ukrainian).

Franko, I. (2004). Vybrani tvory u trokh tomakh: Drohobych (in Ukrainian).

Kleren Manih "Osnovy tvorchoho metodu Ivana Franka" Vybrane t. 1 Miunkhen 1971 (in Ukrainian).

Universalnyi slovnyk - entsyklopediia (2001). Kyiv Lviv (in Ukrainian). 